\title{
Phytopathology
}

\section{Networks in Plant Epidemiology: From Genes to Landscapes, Countries, and Continents}

\author{
Mathieu Moslonka-Lefebvre, Ann Finley, Ilaria Dorigatti, Katharina Dehnen-Schmutz, Tom Harwood, \\ Michael J. Jeger, Xiangming Xu, Ottmar Holdenrieder, and Marco Pautasso
}

First author: AgroParisTech, ENGREF, 19 avenue du Maine, 75732 Paris Cedex 15, France, and Department of Plant Sciences, University of Cambridge, Downing Street, Cambridge CB2 3EA, UK; first, second, sixth, and ninth authors: Division of Biology, Imperial College London, Silwood Park, Ascot, SL5 7PY, UK: second author: West Virginia University, 1026 Agricultural Science, P.O. Box 6108, Morgantown, WV 26506; third author: Department of Mathematics, University of Trento, 38123 Povo TN, Italy; fourth author: Warwick HRI, University of Warwick, Wellesbourne, Warwick, CV35 9EF, UK; fifth author: CSIRO Ecosystem Sciences, Black Mountain Laboratories, ACT 2601, Australia; seventh author: Plant Pathology, East Malling Research, East Malling, Kent, ME19 6BJ, UK; and eighth author: Forest Pathology \& Dendrology, Institute of Integrative Biology, Department of Environmental Sciences, ETH Zurich, 8092 Zurich, Switzerland.

\begin{abstract}
Moslonka-Lefebvre, M., Finley, A., Dorigatti, I., Dehnen-Schmutz, K., Harwood, T., Jeger, M. J., Xu, X., Holdenrieder, O., and Pautasso, M. 2011. Networks in plant epidemiology: From genes to landscapes, countries, and continents. Phytopathology 101:392-403.
\end{abstract}

There is increasing use of networks in ecology and epidemiology, but still relatively little application in phytopathology. Networks are sets of elements (nodes) connected in various ways by links (edges). Network analysis aims to understand system dynamics and outcomes in relation to network characteristics. Many existing natural, social, and technological networks have been shown to have small-world (local connectivity with short-cuts) and scale-free (presence of superconnected nodes) properties. In this review, we discuss how network concepts can be applied in plant pathology from the molecular to the landscape and global level. Wherever disease spread occurs not just because of passive/natural dispersion but also due to artificial movements, it makes sense to superimpose realistic models of the trade in plants on spatially explicit models of epidemic development. We provide an example of an emerging pathosystem (Phytophthora ramorum) where a theoretical network approach has proven particularly fruitful in analyzing the spread of disease in the UK plant trade. These studies can help in assessing the future threat posed by similar emerging pathogens. Networks have much potential in plant epidemiology and should become part of the standard curriculum.

Additional keywords: biodiversity, complexity and stability, modeling host-pathogen interactions, network theory, sudden oak death, systems biology.

Corresponding author: M. Pautasso; E-mail address: mrpauta@gmail.com

doi:10.1094/PHYTO-07-10-0192

(c) 2011 The American Phytopathological Society
Networks are sets of nodes connected by links in various ways (Box 1). Although the properties of random networks have already been systematically investigated in the 1960s, a growing body of literature is now using networks in a range of ecological applications, including the study and management of human, animal, and plant diseases $(29,49,58,80,131)$ (Fig. 1). Given the generality and flexibility of the approach, network representations can be used at a variety of levels in plant pathology, from gene expression during host-pathogen interactions, to the development of plant epidemics among fields, farms, and landscapes and to trade movement of plants infected by pathogens or infested by insects among regions and countries.

Network structure has profound effects on the dynamics of an epidemic within a population $(51,61,127)$. In today's globally connected world, social and transportation networks play a crucial role in the spread of human infectious diseases $(21,53,83)$. A network approach provides insights into the transmission of infectious diseases also in animals more generally $(40,45,78,137)$. Although there is an increasing interdisciplinary application of networks in epidemiology, relatively little attention has been paid to these analytical approaches in plant sciences. Hence the need for this review, which aims to summarize recent progress in this rapidly developing field and to highlight research challenges specific to plant pathology.

In today's plant pathology, as in other fields, there is a need for integrating investigations at the molecular, mycelium, plant, regional and international scale $(9,48,102,111,118,120,132)$. Networks can provide such a unifying framework. They can be (i) perceived at an abstract level (e.g., fungal species occurring on the same plant species host), (ii) materialized by a physical structure (e.g., the root system of plant individuals connected by mycorrhiza, or vice versa), and (iii) underlying flows of energy, matter or information (e.g., the exchanges of knowledge, equipment and money among farmers, plant health consultants, researchers and phytopharmaceutical companies). 
A key point in network theory is that physical distance among nodes may only matter to a limited extent $(22,60,110,125)$. This is increasingly recognized in plant pathology, due to the many examples of long-distance movement of pathogens. However, there is a growing consensus among researchers that the number of connections (and its variability among nodes) plays a fundamental role in how networks function and in how epidemic spread in networks can be controlled. This insight may be very helpful for plant health authorities worldwide, wherever these are struggling to cope with ever-increasing volumes in trade of potentially infected plants. By targeting super-connected traders and major pathways, control can be made more efficient and effective.

\section{NETWORKS IN MOLECULAR PLANT PATHOLOGY}

There is much potential in the use of networks at a molecular level (1). Molecular plant pathology is particularly amenable to network-thinking given the possibilities to use networks as a model of the interactions among genes, proteins, enzymes, and other cellular constituents contributing to host resistance or pathogen infection $(86,128)$. An example is given by the network built from the gene-for-gene relationships between rice and various avirulence genes of the pathogen Xanthomonas oryzae (Fig. 2A). In Figure 2A, nodes are isogenic lines of rice that are connected if they share genes with high resistance (with respect to avirulence genes). It is possible to build a similar network with the same data, but using genes as nodes, and connecting them if they share isogenic lines of rice with a certain parameter.

This kind of visualizations can help in identifying particularly promising genes for developing, e.g., host resistance to pathogens. Other types of presentations (e.g., matrices, genetic maps, verbal descriptions, frequency distributions) are equally valuable, but network diagrams are an intuitive way to provide an overview of gene-for-gene relationships in a host-pathogen system (Fig. 2B). Such networks are increasingly used in systems biology $(25,43,46,101)$, where they are for example instrumental in unraveling the role of specific genes in particular cellular functions. Similarly, networks have been frequently used in phylogeographic studies of plant pathogens based on molecular markers, from nested haplotype networks to minimum spanning networks (18, $39,144)$. Networks are of course important in the reconstruction of the tree of life $(32,94)$ and in the study of lateral transfer in prokaryote genome evolution (23). However, there is certainly the opportunity for more frequent use of networks in molecular plant pathology. This not just to improve understanding, but also to help in better managing disease in the field $(20,76)$.

Recent advances in genome sequencing technology are about to further increase the availability of genetic data, both at the intraspecific and community level (109). Metagenomic data from 454 sequencing can be presented in a variety of ways, but may be fruitfully employed also to build networks. For example, when data are available for a certain plant pathogen from multiple locations/hosts, a network can be built based on the similarity among the pathogen strains. Figure 3 shows an example of such network visualization at the interspecific level. This is still based on pathogen presence only, rather than genetic similarity of pathogen strains, but may be helpful in identifying host taxa playing a pivotal role in spreading a certain disease in the seminatural environment, in crop plants, and plants in the trade. Pilot use of 454 sequencing in the study of fungal diversity reminds us of our still limited understanding of the biodiversity of fungi in soils and the phyllosphere $(14,59,75,93)$. It is likely that our

\section{BOX 1}

Key topological parameters of networks. The definitions in the boxes are adapted from the following references: $(2,8,26,37,140)$. Boccaletti et al. (8) provide an exhaustive review on network structure and dynamics.

\begin{tabular}{|c|c|}
\hline Network/graph & $\begin{array}{l}\text { A graph is composed of a set of nodes and a set of links between pairs of nodes. A network is a graph where } \\
\text { nodes and/or links are associated to weights. Such weights, e.g., represent number of plants hosted within a } \\
\text { nursery per time unit (weighted node) or the number of plants transported between two nurseries per time } \\
\text { unit (weighted link). Most authors tend to ignore the distinction between graphs and networks as we do. } \\
\text { Mathematically, an unweighted network is represented by a binary adjacency matrix } \mathbf{A} \text {, where } A(i, j)=1 \text { when } \\
\text { node } i \text { is connected to } j \text { and where } A(i, j)=0 \text { otherwise. }\end{array}$ \\
\hline Nodes/vertices/points & $\begin{array}{l}\text { Nodes (or vertices or points) are the individual units } n_{1}, \ldots, n_{x} \text { composing the network. Depending on the } \\
\text { context, nodes, e.g., represent proteins, cells, plants, nurseries, fields or countries. }\end{array}$ \\
\hline Links/edges/arrows & $\begin{array}{l}\text { Links (or edges) are the connections }(i, j) \text { between nodes } i \text { and } j . \text { When a network is directed, edges are } \\
\text { sometimes called arrows. }\end{array}$ \\
\hline $\begin{array}{l}\text { Directed versus } \\
\text { undirected }\end{array}$ & $\begin{array}{l}\text { A network } \mathbf{A} \text { is undirected when } \mathrm{A}(i, f)=\mathrm{A}(j, 1) \text { for every node } i \text { and } j \text {. When } \mathrm{A}(i, \lambda) \text { is not equal to } \mathrm{A}(j, 1) \text {, that } \\
\text { network } \mathbf{A} \text { is directed. }\end{array}$ \\
\hline Degree & $\begin{array}{l}\text { For any node } i \text {, the degree } k_{i} \text { of } i \text { is the total number of edges from node } i \text { to all other nodes. For directed } \\
\text { graphs, the total number of links going to (or out of) } i \text { is the in-degree of } i \text { (the out-degree of } i \text {, respectively). } \\
\text { The sum of the in- and out-degree is the total-degree of node } i \text {. }\end{array}$ \\
\hline $\begin{array}{l}\text { Neighborhood and } \\
\text { clustering coefficient }\end{array}$ & $\begin{array}{l}\text { The neighborhood } \Gamma_{i} \text { of a node } i \text { is the graph that consists solely of the set } V_{\Gamma i} \text { of nodes connected to } i \text { (not } \\
\text { including } i \text { itself) and of the set } E_{\Gamma i} \text { of all edges connecting such nodes. The clustering coefficient } C_{i} \text { of a node } i \\
\text { characterizes the extent to which nodes adjacent (connected) to any node } i \text { are adjacent to each other. The } \\
\text { average clustering } C \text { of a graph is the average of the clustering of each node of the graph. }\end{array}$ \\
\hline Shortest path length & $\begin{array}{l}\text { The shortest path length } L(i, J) \text { from node } i \text { to node } j \text { is the minimum number of links that must be crossed to } \\
\text { reach } j \text { from } i \text {. The shortest path length } L \text { of a network is the average of the shortest path lengths from all } \\
\text { nodes to all nodes. }\end{array}$ \\
\hline
\end{tabular}


current knowledge of the biodiversity of plant pathogens in seminatural and cultivated ecosystems may be just as narrow.

\section{NETWORKS AND \\ THE COMPLEXITY-STABILITY DEBATE}

Coupling the new sequencing technologies with network theory in plant pathology would enable us to better understand the role of the diversity of both plant hosts and associated microorganisms in shaping plant epidemics. Networks may provide a tool to test mechanisms linking plant diversity and ecosystem susceptibility to plant pathogens: (i) insurance hypothesis: the presence of some nodes (species) insures against the disappearance of others; (ii) redundancy hypothesis: some nodes can be removed without damage to the system; (iii) idiosyncratic hypothesis: the response of the network to the removal of nodes is not simply predictable; (iv) rivet hypothesis: some nodes have a more important role than others in providing stability; and (v) null hypothesis: network functionality is independent of the number of nodes (97). There is increasing observational, experimental, and theoretical evidence that higher intra- and interspecific diversity of plant hosts is associated with lower impact of plant pathogens and pests (36, $57,62,71,91,116)$, but we are still far from understanding the regulating or synergistic effects of the co-occurrence of different plant pathogens and pests in the same ecosystem or over large regions $(19,126,133)$.

In many managed ecosystems, human activities can result in the inadvertent or intended removal of species. For example, disease management may temporarily reduce the abundance of a plant pathogen and of other associated species. Despite the counterintuitive results of some previous complexity-stability models (which implied that more complexity resulted in less stability [80]), recent advances in food web theory (a special application of networks) have made it clearer that biodiversity loss can often be followed by a decrease in ecosystem stability (38). In order to improve the sustainability of agriculture, there is a need for more awareness of the long-term ecological consequences of largescale pesticide application. Studying the complexity/simplicity of food webs in fields/regions cultivated with varying degrees of pesticide use can inform us about the future prospects of such widespread practices. If generalized pesticide use results in simpler food webs, and if simpler food webs are less resilient to system perturbations (e.g., introduced plant pathogens), then long-term pesticide use is a short-sighted practice. There are of course also the issues of pesticide resistance, environmental pollution, and toxic residues in food to consider.

\section{LANDSCAPE EPIDEMIOLOGY AND NETWORKS}

There is an increasing relevance of plant disease outbreaks at the landscape level (102). This may be the consequence of the growing homogeneity of cultivated landscapes, due in turn to larger field sizes, similar choice of crops, and artificial movement of pathogens among different regions. At the same time, plant pathologists are approaching such regional outbreaks with the quantitative tools of landscape ecology (50). Expanding the key

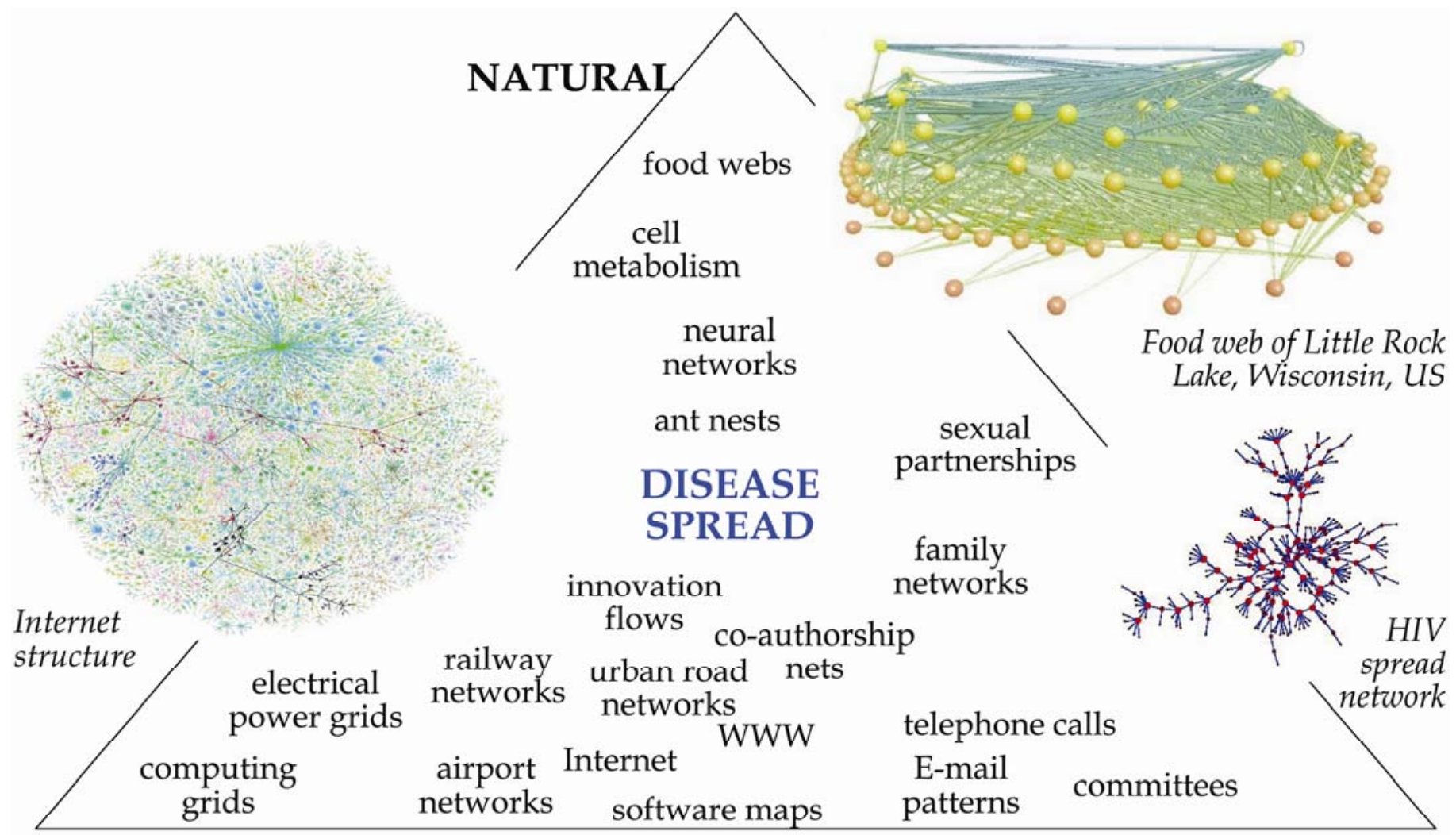

TECHNOLOGICAL

SOCIAL

\section{FIGURE 1}

Epidemiology is just one of the many applications of network theory. Given that (i) diseases are natural phenomena, (ii) technology helps in spreading them (but also in preventing them and managing their effects), and (iii) people are often involved, epidemiology works at the interface of natural, technological, and social networks. The representations of network examples are reprinted from Newman (90), courtesy of H. Burch, B. Cheswick, J. Potterat, and R. Williams. 
role of the classic disease triangle (host-pathogen-environment) over a region of interest, landscape epidemiology studies the regional variation in host presence and susceptibility, pathogen diversity and disease severity, and the extent to which the biotic and abiotic environments are conducive to plant epidemics.

When plant pathological studies were restricted to single geographical locations, there was limited opportunity to think about the connections between stands or fields in different regions. Enlarging the view to a whole landscape and considering different survey plots in the region of interest prompts the question of whether or not pathogens are moving from one sampled area to others. This is a research question that new genetic tools can help investigate and which can be conveniently framed in terms of network theory (6). Given the pervasive presence and activities of human beings, plant diseases are not the sole outcome of the interactions between host, pathogen, and environment (112). The importance of people in moving plant pathogens and in influencing host-pathogen interactions, as well as their environment, is particularly strong at the landscape level (77). Where pathogen dispersal does not occur continuously within a landscape because of trade networks, long-distance connections can be effective shortcuts for plant diseases $(54,82,138)$.

An example of such a situation is provided by the emerging regional outbreaks of Phytophthora ramorum, the causal agent of sudden oak death in the West Coast of the United States, of sudden larch death in Japanese larch plantations in the UK, and Ireland and of leaf blight and twig dieback on a range of ornamental species in the United States and various European countries $(42,141)$. For $P$. ramorum, the epidemics in the horticultural trade and those in the seminatural landscape can be viewed as only partly independent systems (as shown for England and Wales [143]). In the West Coast of the United States, two predominant pathways (forest versus horticulture) of $P$. ramorum migration have been identified combining genetic network analysis and data on trace forward and trace back data on movement of plants in the nursery trade (39). However, it is clear that the pathogen was introduced from nurseries into the wild, given that $P$. ramorum populations in nurseries are genetically ancestral to all Californian forest populations (39). A realistic integration of the horticultural movement of potentially infected plants in spatially explicit models of disease development has been shown to be necessary for a proper simulation of the epidemiological system for $P$. ramorum and other similar plant pathogens also in England and Wales (47). There is much scope for an integration of genetic investigations reconstructing the spread of $P$. ramorum in the plant trade $(39,79,104)$ with network modeling scenarios developed to predict future developments of the epidemic and to make policy and management more effective.

For example, key recommendations for policy and management have been obtained from a susceptible-exposed-infectious-susceptible model of $P$. ramorum epidemic development in the UK including information on the spatial distribution of potential hosts, as well as a realistic super-imposed network of commercial plant movements (47). The current policy relative to $P$. ramorum in plant traders of the UK and other European countries comprises both surveys of national plant health authorities and mandatory reporting of the pathogen by nursery growers (143). A series of simulation experiments were run, with variation in the epidemic pressure and in the connection between seminatural vegetation and horticultural trade, with or without disease spread in commercial trade, and with or without inspections-with-eradication. The results of the simulations suggest that the current inspection policy is likely to control most epidemics (epidemic final size was reduced by inspections by about $90 \%$ ) and to avoid escape of the
FIGURE 2

A, Network of gene-for-gene relationships between rice and diverse avrBs3/pthA avirulence genes in Xanthomonas oryzae pv. oryzae (based on coexistence of high resistance in the same gene for different isogenic lines of rice; the strength of the lines reflects the number of connections, i.e., the number of genes with high resistance in the two isogenic lines of rice so connected). Data obtained from Wu et al. (142). B, Scaled illustration of the distribution of virulence differences between isolates of wheat stem rust from the eastern and central United

States that originated asexually. Each sphere represents a cluster of genetically similar isolates, and its diameter is proportional to the maximum number of loci at which isolates of the cluster differ in virulence. Distances between spheres are proportional to the mean number of virulence differences between clusters (reprinted from Roelfs and Groth [107]), with kind permission of The American Phytopathological Society).
A

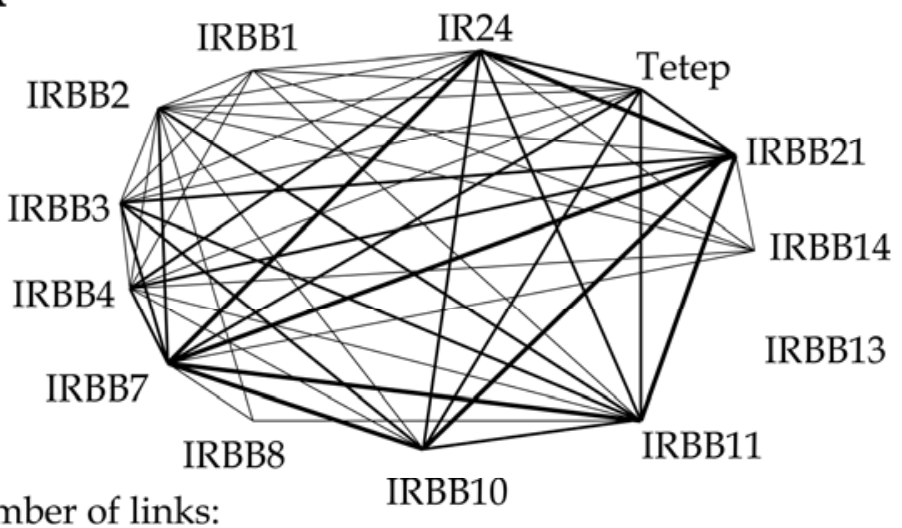

Number of links:

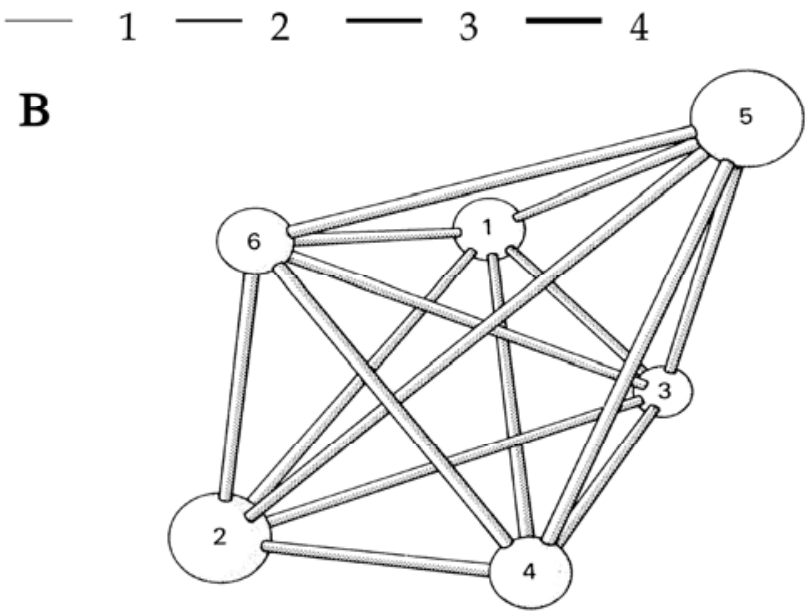


FIGURE 3

Web of genera susceptible to Phytophthora ramorum in

A, the seminatural environment (woodland, historic gardens) and $\mathbf{B}$, the horticultural trade (plant nurseries and retail centers). Two genera are connected if $P$. ramorum was detected on individual plants of these genera at the same location (2003 to 2005, England and Wales, data provided by DEFRA, UK). The connection strength reflects the number of locations with co-occurrence of the infected plant genera. Modified from Pautasso et al. (96).
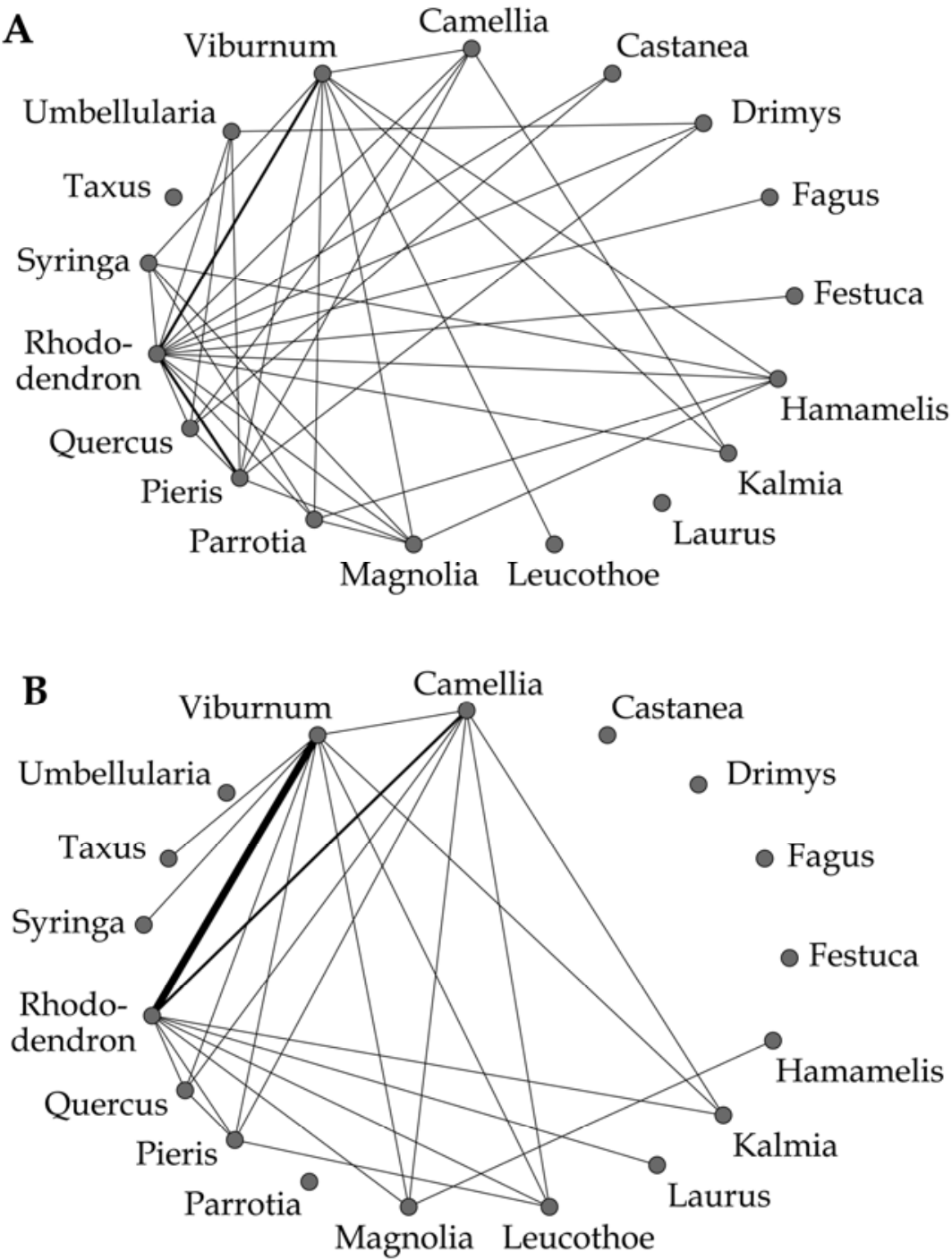

\section{BOX 2}

Key quantities for epidemiological dynamics in network.

Epidemic threshold $\lambda$

Epidemic final size $S$

In- and out-degree

Correlation between in- and out-degree
Let $p_{t}$ be the probability of transmission and $p_{p}$ the one of persistence. $\left(1-p_{p}\right)$ is the probability of recovery. At the epidemic threshold $p_{t}^{*} /\left(1-p_{p}{ }^{*}\right)=\lambda$, the epidemic neither grows nor dies out (equilibrium conditions). When $p_{t} /\left(1-p_{p}\right)>\lambda$, the epidemic develops. When $p_{t} /\left(1-p_{p}\right)<\lambda$, the epidemic dies out.

For networks where nodes are either infected or not, $S$ can be defined as the number of infected nodes at the epidemic threshold $\lambda$. For networks where nodes are infected along a continuum of infectious states (e.g., plant nurseries where a fraction of the total number of plants is infected), $S$ can be assessed at the epidemic threshold either as the sum of infectious status of all nodes or as the number of nodes with an infectious status higher than an arbitrary value.

Number of links into and from a node, respectively. In directed networks, epidemic final size is generally positively correlated to the out-degree of the initially infected node (99).

Correlation coefficient between incoming and outgoing links of a node across all nodes of a network. Other things being equal, and unless networks are sparsely connected, the correlation between in- and out-degree is negatively associated with the epidemic threshold (87).

Connectance

The connectance $\mathrm{C}\left(\mathrm{C}=\right.$ Links/Nodes $\left.{ }^{2}\right)$ is the fraction of links realized within a network. A network can only have as many links as its squared number of nodes (including self-loops and considering a link from node $z$ to $W$ separately from a link from $w$ to $z$ ). For a given network structure and correlation between in- and out-degree, the higher the connectance, the lower the epidemic threshold (87). 
pathogen into the seminatural environment from the horticultural trade. However, in some simulations, escape did occur, thus emphasizing the importance of stochasticity and initial conditions in plant epidemic development in networks (47).

\section{THE HORTICULTURAL TRADE AS A COMPLEX NETWORK}

There are many examples of unintended introductions of exotic plant pathogens which have resulted in considerable economic losses to the horticultural, agricultural and food industries (44, 106,139). Emerging plant epidemics are in many cases a threat not only to global and regional food security (3) but also to the health of seminatural and pristine ecosystems $(11,65,66)$. The rapid structural development in the regional and international connectivity due to affordable long-distance transport and outsourcing of manufacturing, as well as labor-intensive production (including horticulture [24]), is confronted from a biosecurity perspective by different countries in various ways $(28,64,73,74)$. For many countries, the growing security risk posed by plant pathogens is likely to be exacerbated by climate changes $(41,115)$. Together with increased trade and network connectivity, climate change may facilitate the spread of new plant pathogens because it is likely to increase the potential climatic suitability to such pathogens of regions which previously could not be colonized $(95,108,134)$. Although there is evidence that the structure of contact networks (Fig. 4) can have a key influence on the epidemic threshold of diseases spreading in such networks, little is known about the structure of regional and international horticultural trade networks.

Moreover, most research in network epidemiology has relied so far on models of disease development in large-size net- works (thousands of nodes or more) and there have been relatively few theoretical investigations on whether results obtained for large-size and infinite networks also apply to small-size networks (hundreds of nodes or less). Small-size networks are relevant not only for regional horticultural trade systems, but also at an international level when considering countries as individual nodes. Similarly, much attention has been paid to epidemics in undirected networks. Undirected networks have symmetric links (i.e., the connection from producer $x$ to wholesaler $z$ implies the link from $z$ to $x$ ) (Boxes 1 and 2). However, the probability that a plant grower will be linked to a retail center will tend to be different from the reverse connection. This makes it necessary to use asymmetric adjacency matrices (tables of links among nodes which do not necessarily have reverse connections) in order to study plant epidemics in realistic trade networks.

Figure 5A shows an example of epidemic development (susceptible-infected-susceptible model) in a directed network. The epidemic is started at a single node. Nodes with a connection from the starting node will be infected at the next time step with a certain probability of transmission. In turn, already infected nodes will be infected at the next time step depending on their infection status and on a certain probability of persistence. For simplicity's sake, the probability of infection transmission is the same for all connections in a given network replicate. Similarly, the probability of infection persistence is the same for all nodes in a certain network replicate. For each network structure, the two probabilities of persistence and transmission define an epidemic threshold, which is independent of the starting node of the epidemic (98) (Fig. 5B). This epidemiological model does not result in either susceptible or infected nodes, as nodes will have an

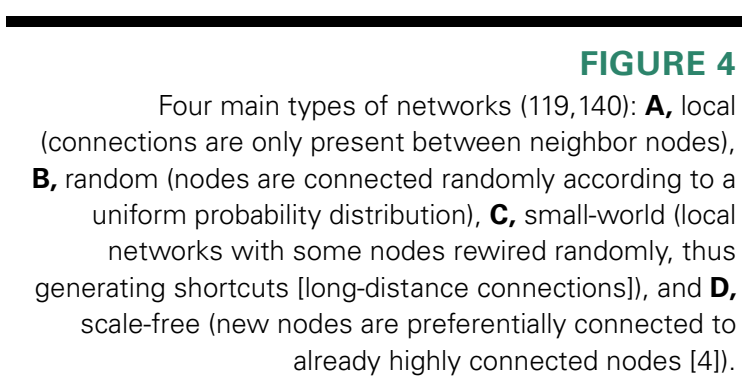

already highly connected nodes [4]).

\section{A}
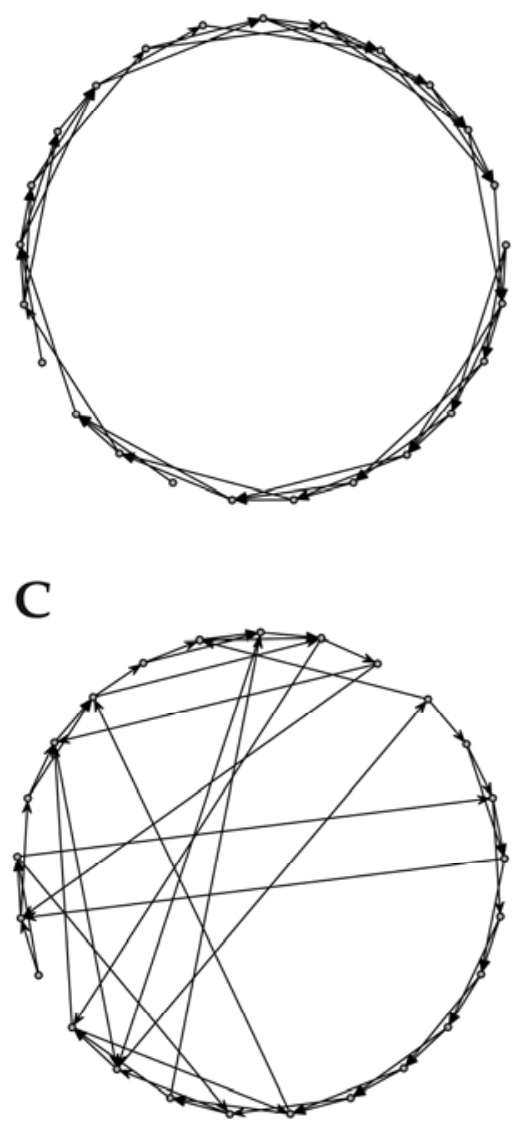

B

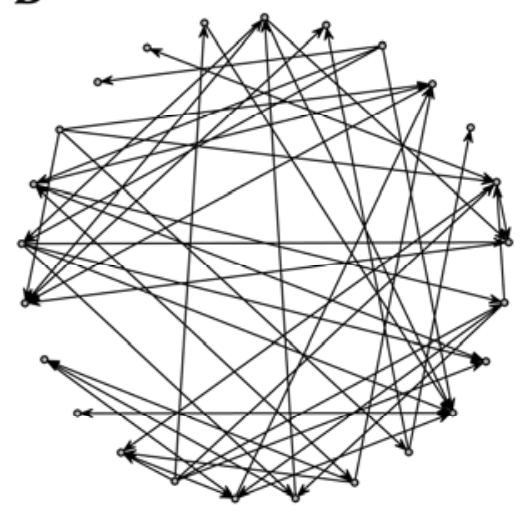

D

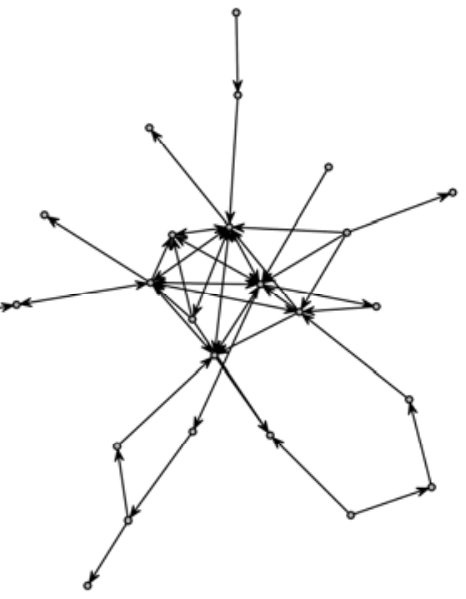

Vol. 101, No. 4, 2011 
A

$\mathrm{p}_{\mathrm{t}}$ probability of infection transmission

p probability of infection persistence
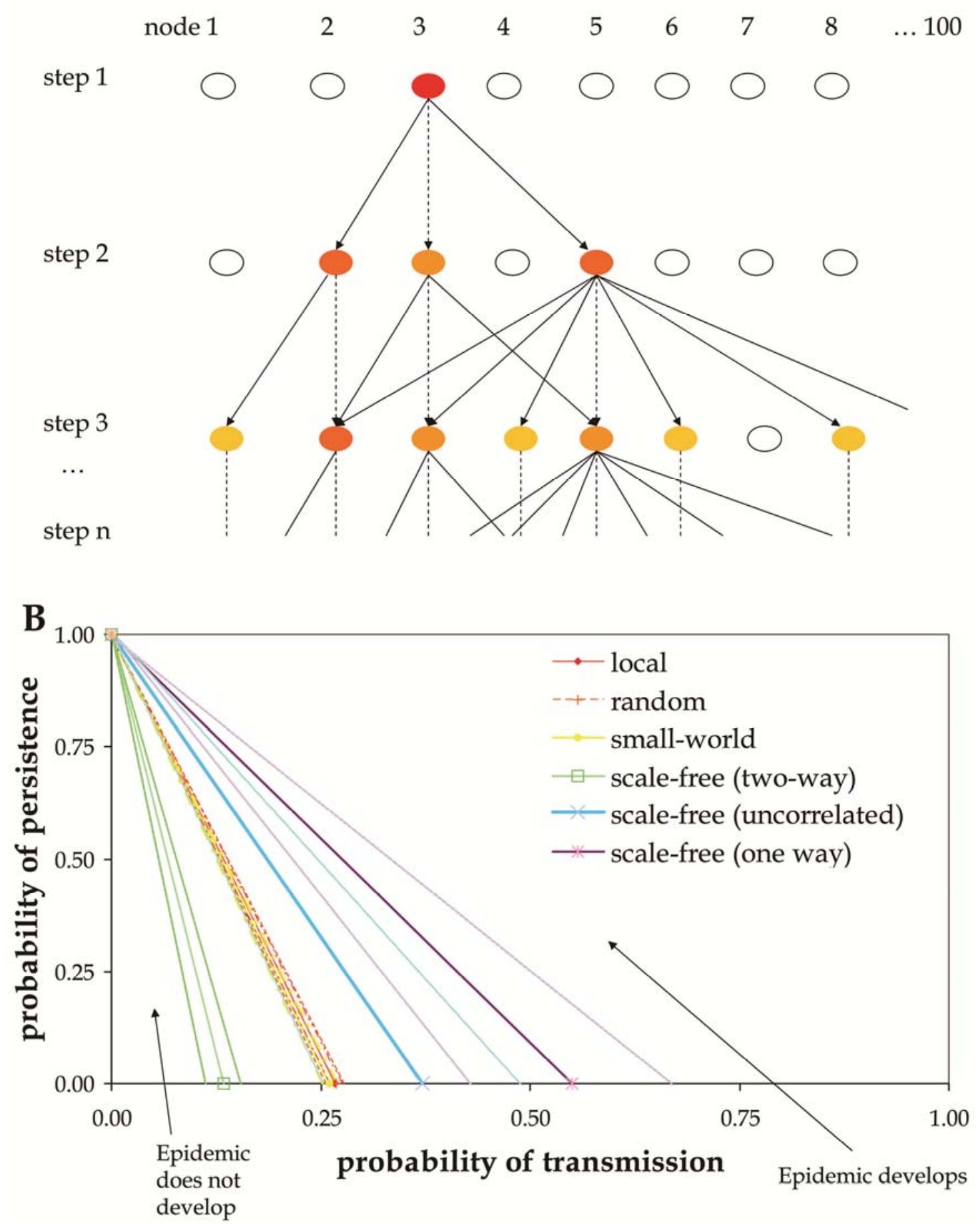

\section{FIGURE 5}

A, Conceptual model of the analyses $(87,98,99)$. A simple model of disease spread in a directed network based on two parameters (probability of infection persistence in an infected node and probability of infection transmission between connected nodes). Node color conveys infection status (from red to white: shift from maximal to minimal infection). Steps are time steps. B, Epidemic threshold of small-size directed networks as a function of the probability of infection persistence and the probability of infection transmission (based on the model in panel A, and modified from 98). Outer lines are confidence intervals (standard deviation) for 100 replicate networks with a given structure. Local, random, and small-world threshold and confidence interval lines overlap with each other. Two-way: correlation between links in and out of nodes $>0.2$ (super-connected nodes have many incoming and outgoing links). One-way: correlation between links in and out of nodes $<-0.2$ (super-connected nodes have either many incoming links and a few outgoing links or many outgoing links and a few incoming links). 
infection status along a continuum. This better captures the reality of the nursery trade, as plant growers, wholesalers and retailers are typically not completely infected, but will tend to have a certain proportion of infected plants at a given point in time.

In this epidemiological model along a continuum of node infection in a directed, small-size network, heterogeneity in the contact structure (a few nodes with many links but most nodes with a few links, i.e., a scale-free structure) can markedly lower invasion thresholds (the boundary between no epidemic and an epidemic) compared with local, small-world, and random structures (Fig. 4; 58,100). Epidemic thresholds are lower for small-size, directed networks with the presence of super-connected individuals, provided there is a correlation between the number of outgoing and incoming links among nodes (Fig. 5B; Box 2). This result implies that in small-size horticultural networks, targeted control toward commercial players with a high number of connections (both in and out of them) is likely to make disease control more effective than random or even systematic phytosanitary approaches.

The importance of the correlation between incoming and outgoing links across nodes of the network is confirmed at different levels of connectance, irrespective of the network structure (local, random, small-world, and scale-free) and despite variation in the clustering coefficient (87). Targeted control can thus be successful in the presence of heterogeneities in the degree (number of links; Box 2 for further definitions) of nodes, even when there is un-
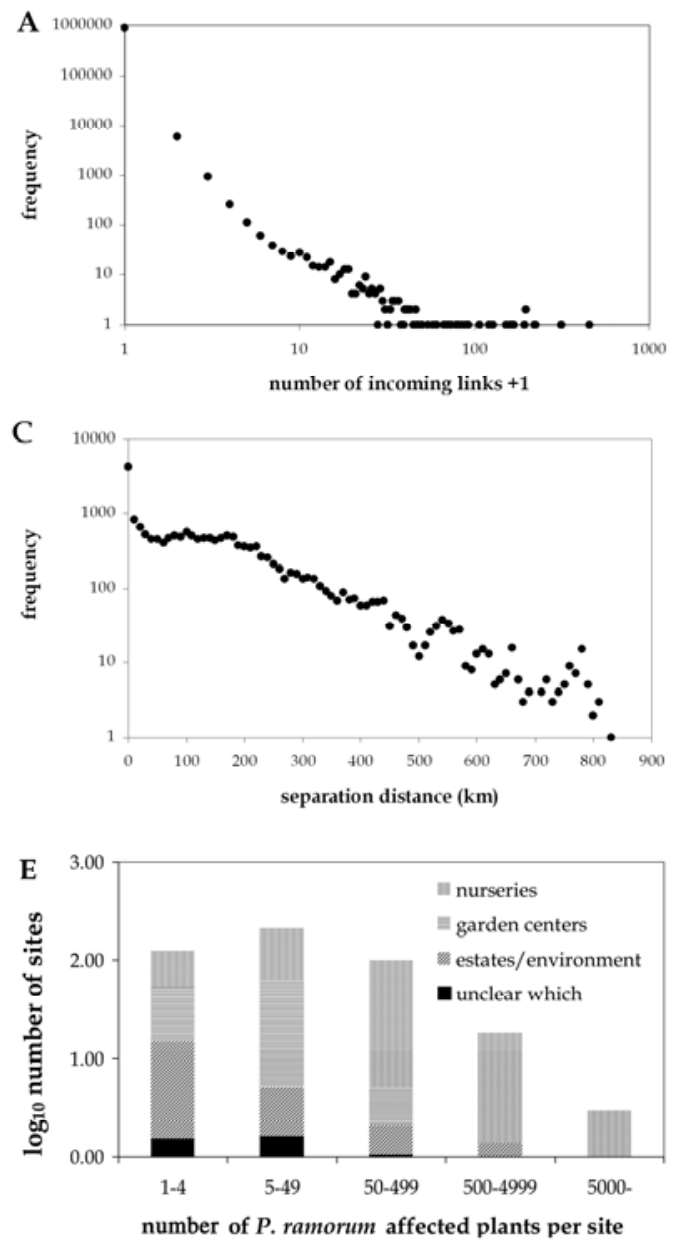

certainty in the contact structure of a trade network (as is the case for many exchange systems of plants and their associated organisms). Figure 5B shows that it is possible to bring an epidemic under control by changing the structure of the network, without having to decrease the probability of infection persistence and/or of transmission. In the presence of super-connected nodes, the most effective way to achieve such epidemic control is to move from a two-way to a one-way network, i.e., from a network with positive correlation among links in and out of nodes, to a network with a negative correlation of in- and out-links.

Depending on the characteristic of the pathogen, the putative structure of the network, the estimated probabilities of persistence and of transmission, and the budget constraints at a given point in time, control strategies may have to focus on reducing transmission and/or persistence without changing the links in the system, but it is possible that influencing the network structure may be more costeffective than the traditional inspection and quarantine policies. Similar considerations apply to influencing hierarchical categories in networks of various structure and connectance level, i.e., the proportions of producers, wholesalers and retailers in a trade network. Other things being equal, for non-scale-free network structures adding wholesalers to a network is associated with an increase in the correlation among links in and out of nodes, and thus with a reduction in the epidemic threshold (100). The opposite result is obtained for the proportion of producers and retailers.
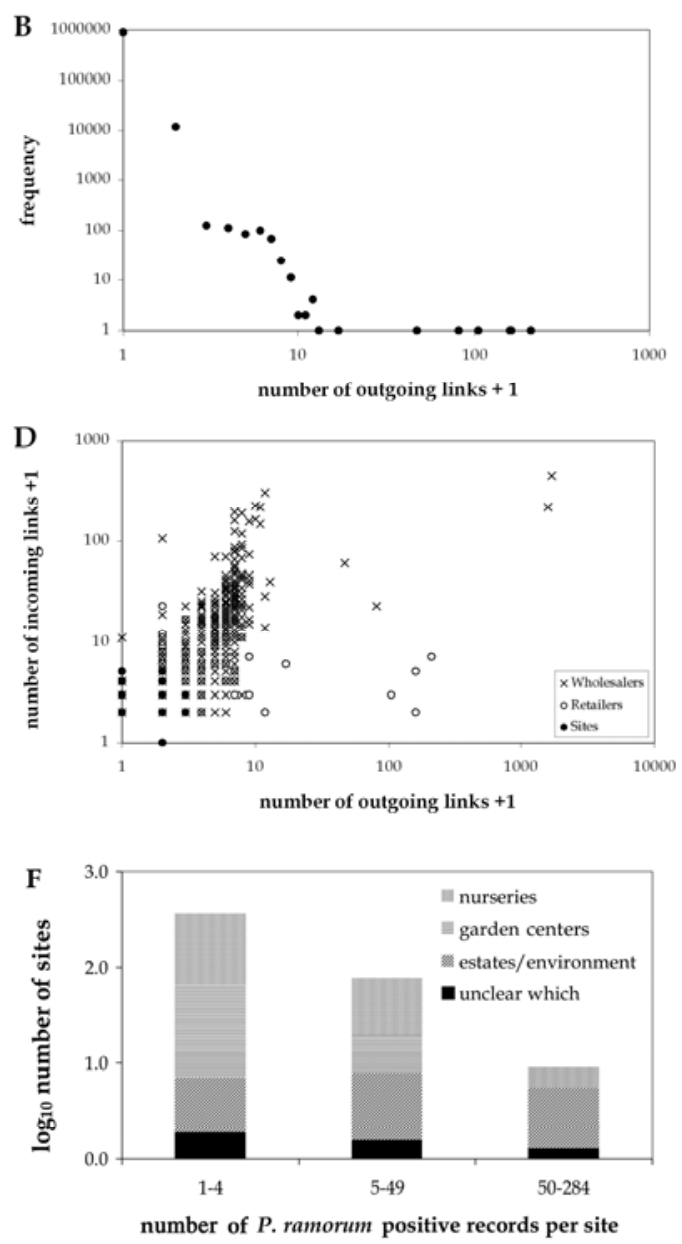

\section{FIGURE 6}

Frequency distribution for a realistic reconstruction of the horticultural trade in the UK of $\mathbf{A}$, number of incoming links, $\mathbf{B}$, number of outgoing links, and $\mathbf{C}$, link distances. D, Correlation between number of incoming and outgoing links. Data from spatially explicit simulations of the spread of Phytophthora ramorum in the UK (46). Frequency distribution of number of affected $P$. ramorum $\mathbf{E}$, plants and $\mathbf{F}$, records per site in England and Wales (2003 to 2006), data from Defra, UK. 
A result which appears to be present regardless of network type and level of connectance is the strong correlation at the threshold conditions between epidemic final size (the number of nodes with infection above an arbitrary value at equilibrium, or the sum of the infection status of all nodes at equilibrium) and the number of out-going connections of the starting node of the epidemic (99). In terms of $P$. ramorum, these epidemic final sizes (although no equilibrium may ever be reached in the real world) would be, for example, the number of nurseries/retail centers with more than a certain proportion of plants infected, or the overall number of infected plants in all nurseries/retail centers. The implication is again that heterogeneity in the contact structure of horticultural trade networks is likely to increase the risk of major epidemics occurring, if by chance a major producer with a high number of out-links is infected.

Worryingly, little is known not only about the current contact structure of horticultural networks within and among nations, but also about how this is changing. Simulations of the spread of $P$. ramorum in the UK incorporating realistic assumptions about the horticultural trade (47) result in heterogeneity in the number of incoming and outgoing links, as well as the presence of smallworld properties (long-distance connections), and a weak correlation among number of incoming and outgoing links (Fig. 6). The heterogeneity in the network structure could be at least in part responsible for the observed heterogeneity in the number of $P$. ramorum affected plants and records per site: most sites where $P$. ramorum was detected have only one or a few plants infected, whereas a few sites have hundreds or thousands of individual plants infected (Fig. 6).

Links among horticultural traders are realized by plant shipments, which may or may not involve plants susceptible to $P$. ramorum, which in turn may or may not be infected by the pathogen (and may or may not show symptoms of the disease, thus making it not straightforward for infected shipments to be detected before departure, en route or on arrival). The presence of a link between plant traders is thus distinct from the probability of transmitting the disease along that link. What is necessary in order to establish the network type underlying the spread of $P$. ramorum are data on the number of links of traders of the major ornamental plants susceptible to $P$. ramorum (e.g., Calluna, Camellia, Erica, Hamamelis, Magnolia, Pieris, Rhododendron, Syringa, Vaccinium, and Viburnum).

An increase in the connectivity among nations and continents due to higher volume in trade of crops, plants, and flowers (Fig. 7) may have consequences not only for the likelihood of intro- duction of new pathogens and other organisms associated with plants $(27,113,135)$, but also for gene flow and thus for the evolutionary potential of plant pathogens $(70,81)$. Results from the modeling of disease spread in small-size networks call therefore for the long-term collection of data on the number and degree distribution of plant producers, wholesalers, and retailers in different nations (100). There is the need for comparable longterm data on the trade volumes in ornamental, horticultural, and agricultural crops among countries, regions, and individual firms.

\section{FUTURE CHALLENGES IN PLANT NETWORK EPIDEMIOLOGY}

We believe networks are likely to provide a useful tool in understanding and managing plant epidemics in a changing world. In addition to asymmetry (directed links), models of disease spread in the plant trade need to add dynamic (8) and weighted (5) features to the networks investigated. Real-world plant trade networks are neither static in their structure nor uniform in the strength of the connections. The relatively rare use of network epidemiology in botanical science compared with what has happened in human and animal pathology $(13,58,89)$ may be due to lack of suitable data for plant diseases, but could well change in the future with the adoption of the latest genetic technologies also in plant sciences. Examples of future challenges for a successful use of network theory in plant disease epidemiology include the following.

- Integrating network approaches with recent advances in probabilistic modeling of phytosanitary inspection policies (121-124) and with existing methodologies such as cluster, path, and principal component analysis.

- Merging models of plant disease spread and control in networks with economic assumptions on the availability of resources and the behavior of human agents to obtain more realistic epidemic management scenarios $(31,35,52,63,69)$.

- Moving from descriptive studies of patterns in network structure to testing hypotheses explaining underlying processes (88).

- Learning from related developments in using network theory in (plant) genetics, ecology, and evolution $(7,15,16,22,33,103$, 129).

- Adding network theory to the traditional plant epidemiology and botanical curriculum $(17,34,72,130)$.

- Adapting available software to visualize genetic, social, and ecological networks for plant epidemiology data $(37,67,68$, 105,114).
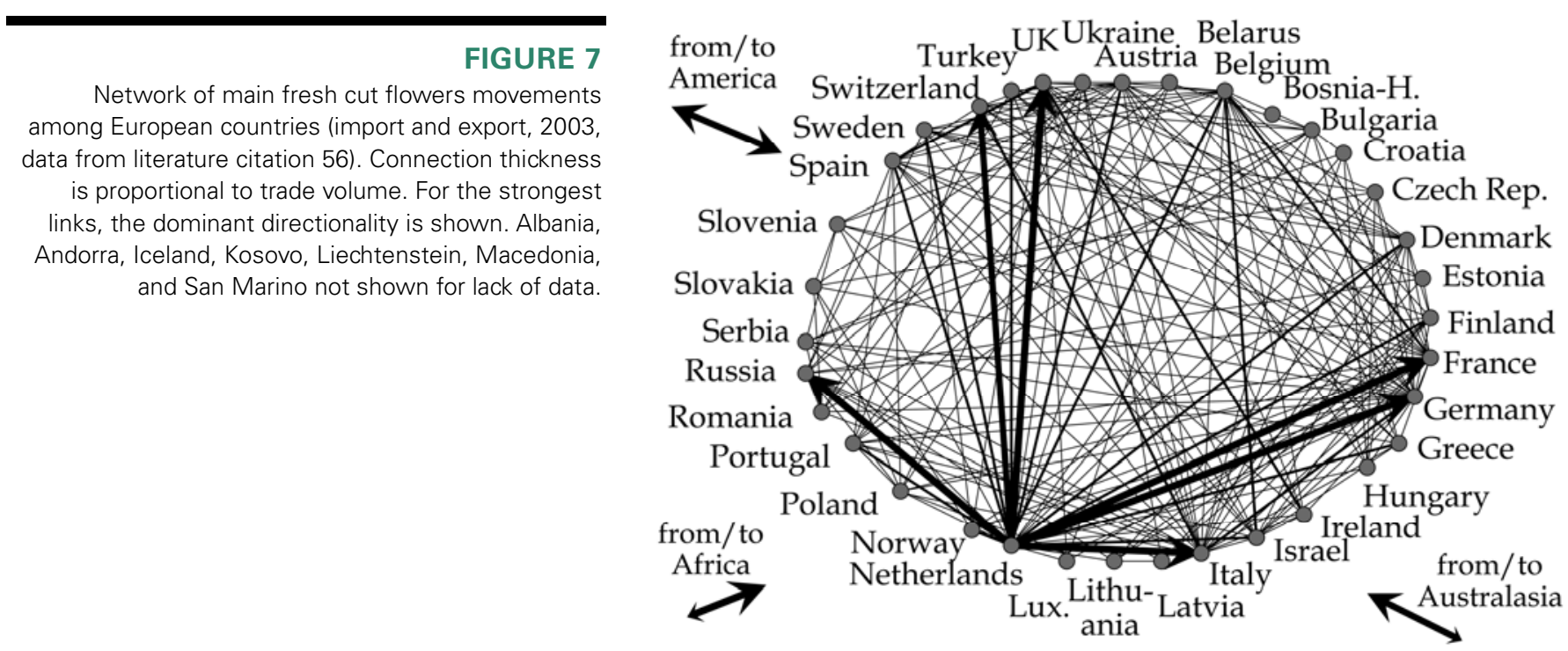
- Using insights from network theory to facilitate dissemination of plant health knowledge among plant pathologists, farmers and consumers (85).

- Adopting network concepts in philosophical discussions about, e.g., causation in epidemiology and the nature of health/disease $(12,30,117)$.

- Investigating the combined effect of the forecasted expansion of agricultural trade networks and changes in climate for better mapping the likely severity of future plant epidemics $(10,55$, $84,92,136)$

\section{ACKNOWLEDGMENTS}

We thank C. Brasier, S. Denman, T. Döring, M. Garbelotto, G. Hirsch, A. Inman, V. Kertesz, C. Manceau, J. Parke, L. Pellis, T. Rafoss, V. Sybren, F. van den Bosch, P. Weisberg, and J. Webber for insights and discussions, and N. Grünwald, T. Matoni, M. Shaw, and anonymous reviewers for helpful comments on a previous draft. This review was partly funded by the Rural Economy and Land Use (RELU) Programme, UK, and by the French Ministries in charge of Agriculture and Sustainable Development.

\section{LITERATURE CITED}

1. Almaas, E. 2007. Biological impacts and context of network theory. J. Exp. Biol. 210:1548-1558.

2. Assenov, Y., Ramirez, F., Schelhorn, S. E., Lengauer, T., and Albrecht, M. 2008. Computing topological parameters of biological networks. Bioinformatics 24:282-284.

3. Bandyopadhyay, B., and Frederiksen, R. A. 1999. Contemporary global movement of emerging plant diseases. Ann. N.Y. Acad. Sci. 894:28-36.

4. Barabasi, A. L., and Albert, R. 1999. Emergence of scaling in random networks. Science 286(5439):509-512.

5. Barrat, A., Barthelemy, M., Pastor-Satorras, R., and Vespignani, A. 2004. The architecture of complex weighted networks. Proc. Natl. Acad. Sci. USA 101:3747-3752.

6. Biek, R., and Real, L. A. 2010. The landscape genetics of infectious disease emergence and spread. Mol. Ecol. 19:3515-3531.

7. Blick, R., and Burns, K. C. 2009. Network properties of arboreal plants: Are epiphytes, mistletoes and lianas structured similarly? Persp. Plant Ecol. Evol. Syst. 11:41-52.

8. Boccaletti, S., Latora, V., Moreno, Y., Chavez, M., and Hwang, D. U. 2006. Complex networks: Structure and dynamics. Phys. Rep.-Rev. Sect. Phys. Lett. 424:175-308.

9. Boddy, L., Wood, J., Redman, E., Hynes, J., and Fricker, M. D. 2010. Fungal network responses to grazing. Fungal Genet. Biol. 47:522-530.

10. Bradley, B. A., Wilcove, D. S., and Oppenheimer, M. 2010. Climate change increases risk of plant invasion in the Eastern United States. Biol. Inv. 12:1855-1872.

11. Brasier, C. M. 2008. The biosecurity threat to the UK and global environment from international trade in plants. Plant Pathol. 57:792-808.

12. Broadbent, A. 2009. Causation and models of disease in epidemiology. Stud. Hist. Phil. Sci. C 40:302-311.

13. Brooks, C. P., Antonovics, J., and Keitt, T. H. 2008. Spatial and temporal heterogeneity explain disease dynamics in a spatially explicit network model. Am. Nat. 172:149-159.

14. Buée, M., Reich, M., Murat, C., Morin, E., Nilsson, R. H., Uroz, S., and Martin, F. 2009. 454 Pyrosequencing analyses of forest soils reveal an unexpectedly high fungal diversity. New Phytol. 184:449-456.

15. Buldyrev, S. V., Parshani, R., Paul, G., Stanley, H. E., and Havlin, S. 2010. Catastrophic cascade of failures in interdependent networks. Nature 464:1025-1028.

16. Burns, K. C., and Zotz, G. 2010. A hierarchical framework for investigating epiphyte assemblages: Networks, meta-communities, and scale. Ecology 91:377-385.

17. Callis, K. L., Christ, L. R., Resasco, J., Armitage, D. W., Ash, J. D., Caughlin, T. T., Clemmensen, S. F., Copeland, S. M., Fullman, T. J., Lynch, R. L., Olson, C., Pruner, R. A., Vieira-Neto, E. H. M., West-Singh, R., and Bruna, E. M. 2009. Improving Wikipedia: Educational opportunity and professional responsibility. Trends Ecol. Evol. 24:177-179.

18. Carbone, I., and Kohn, L. M. 2001. Multilocus nested haplotype networks extended with DNA fingerprints show common origin and fine-scale, ongoing genetic divergence in a wild microbial metapopulation. Mol. Ecol. 10:2409-2422.
19. Cheatham, M. R., Rouse, M. N., Esker, P. D., Ignacio, S., Pradel, W., Raymundo, R., Sparks, A. H., Forbes, G. A., Gordon, T. R., and Garrett, K. A. 2009. Beyond yield: Plant disease in the context of ecosystem services. Phytopathology 99:1228-1236.

20. Colbach, N. 2010. Modelling cropping system effects on crop pest dynamics: How to compromise between process analysis and decision aid. Plant Sci. 179:1-13.

21. Colizza, V., and Vespignani, A. 2008. Epidemic modeling in metapopulation systems with heterogeneous coupling pattern: Theory and simulations. J. Theor. Biol. 251:450-467.

22. Cumming, G. S., Bodin, Ö., Ernstson, H., and Elmqvist, T. 2010. Network analysis in conservation biogeography: Challenges and opportunities. Divers. Distrib. 16:414-425.

23. Dagan, T., Artzy-Randrup, Y., and Martin, W. 2008. Modular networks and cumulative impact of lateral transfer in prokaryote genome evolution. Proc. Natl. Acad. Sci. USA 105:10039-10044.

24. Dehnen-Schmutz, K., Holdenrieder, O., Jeger, M. J., and Pautasso, M. 2010. Structural change in the international horticultural industry: Some implications for plant health. Sci. Hortic. 125:1-15.

25. Dietz, K.-J., Jacquot, J.-P., and Harris, G. 2010. Hubs and bottlenecks in plant molecular signalling networks. New Phytol. 188:919-938.

26. Dormann, C. F., Frund, J., Bluthgen, N., and Gruber, B. 2009. Indices, graphs and null models: Analyzing bipartite ecological networks. Open Ecol. J. 2:7-24.

27. Drew, J., Anderson, N., and Andow, D. 2010. Conundrums of a complex vector for invasive species control: A detailed examination of the horticultural industry. Biol. Inv. 12:2837-2851.

28. Eagling, D. 2007. Australian trade in agricultural food products-The challenge for plant pathologists. Aust. Plant Pathol. 36:539-542.

29. Eames, K. T. D., and Read, J. M. 2008. Networks in epidemiology. Pages 79-90 in: Bio-Inspired Computing and Communication. P. Lio, E. Yoneki, and D. C. Verma, eds. Springer, Berlin.

30. Ereshefsky, M. 2009. Defining 'health' and 'disease'. Stud. Hist. Phil. Sci. C 40:221-227.

31. Fenichel, E. P., Horan, R. D., and Hickling, G. J. 2010 Management of infectious wildlife diseases: Bridging conventional and bioeconomic approaches. Ecol. Appl. 20:903-914.

32. Forest, F. 2009. Calibrating the tree of life: Fossils, molecules and evolutionary timescales. Ann. Bot. 104:789-794.

33. Fortuna, M. A., Albaladejo, R. G., Fernández, L., Aparicio, A., and Bascompte, J. 2009. Networks of spatial genetic variation across species. Proc. Natl. Acad. Sci. 106:19044-19049.

34. Fowke, L. 2010. Creative young minds plus serendipity-A recipe for science. Botany 88:443-451.

35. Funk, S., Salathé, M., and Jansen, V. A. A. 2010. Modelling the influence of human behaviour on the spread of infectious diseases: A review. J. R. Soc. Interface 7:1247-1256.

36. Garrett, K. A., Zúñiga, L. N., Roncal, E., Forbes, G. A., Mundt, C. C., Su, Z., and Nelson, R. J. 2009. Intraspecific functional diversity in hosts and its effect on disease risk across a climatic gradient. Ecol. Appl. 19:1868-1883.

37. Garroway, C. J., Bowman, J., Carr, D., and Wilson, P. J. 2008. Applications of graph theory to landscape genetics. Evol. Appl. 1:620-630.

38. Gilbert, A. J. 2009. Connectance indicates the robustness of food webs when subjected to species loss. Ecol. Indic. 9:72-80.

39. Goss, E. M., Larsen, M., Chastagner, G. A., Givens, D. R., and Grünwald, N. J. 2009. Population genetic analysis infers migration pathways of Phytophthora ramorum in US nurseries. PLoS Pathog. 5:e1000583.

40. Green, D. M., Gregory, A., and Murno, L. A. 2009. Small- and large-scale network structure of live fish movements in Scotland. Prev. Vet. Med. 91:261-269.

41. Gregory, P. J., Johnson, S. N., Newton, A. C., and Ingram, J. S. I. 2009. Integrating pests and pathogens into the climate change/food security debate. J. Exp. Bot. 60:2827-2838.

42. Grünwald, N. J., Goss, E. M., and Press, C. M. 2008. Phytophthora ramorum: A pathogen with a remarkably wide host range causing sudden oak death on oaks and ramorum blight on woody ornamentals. Mol. Plant Pathol. 9:729-740.

43. Gstaiger, M., and Aebersold, R. 2009. Applying mass spectrometry-based proteomics to genetics, genomics and network biology. Nature Rev. Gen. 10:617-627.

44. Gullino, M. L., and Garibaldi, A. 2007. Critical aspects in management of fungal diseases of ornamental plants and directions in research. Phytopathol. Mediterr. 46:135-149.

45. Hamede, R. K., Bashford, J., McCallum, H., and Jones, M. 2009. Contact networks in a wild Tasmanian devil (Sarcophilus harrisii) population: Using social network analysis to reveal seasonal variability in social behaviour and its implications for transmission of devil facial tumor disease. Ecol. Lett. 12:1147-1157.

46. Haruta, S., Kato, S., Yamamoto, K., and Igarashi, Y. 2009. Intertwined 
interspecies relationships: Approaches to untangle the microbial network. Environ. Microbiol. 11:2963-2969.

47. Harwood, T. D., Xu, X. M., Pautasso, M., Jeger, M. J., and Shaw, M. W. 2009. Epidemiological risk assessment using linked network and grid based modelling: Phytophthora ramorum and $P$. kernoviae in the UK. Ecol. Model. 220:3353-3361.

48. Heaton, L. L. M., López, E., Maini, P. K., Fricker, M. D., and Jones, N. S. 2010. Growth-induced mass flows in fungal networks. Proc. R. Soc. B 277:3265-3274.

49. Hill, A. L., Rand, D. G., Nowak, M. A., and Christakis, N. A. 2010. Emotions as infectious diseases in a large social network: The SISa model. Proc. R. Soc. B 277:3827-3835.

50. Holdenrieder, O., Pautasso, M., Weisberg, P. J., and Lonsdale, D. 2004. Tree diseases and landscape processes: The challenge of landscape pathology. Trends Ecol. Evol. 19:446-452.

51. Hollingsworth, D. T. 2009. Controlling infectious disease outbreaks: Lessons from mathematical modelling. J. Publ. Health Policy 30:328-341.

52. Holmes, T. P., Bell, K. P., Byrne, B., and Wilson, J. S. 2008. Economics aspects of invasive forest pest management. Pages 381-406 in: The Economics of Forest Disturbances-Wildfires, Storms, and Invasive Species. T. P. Holmes, J. P. Prestemon, and K. L. Abt, eds. Springer, Berlin.

53. Hufnagel, L., Brockmann, D., and Geisel, T. 2004. Forecast and control of epidemics in a globalized world. Proc. Natl. Acad. Sci. USA 101:1512415129.

54. Hulme, P. E. 2009. Trade, transport and trouble: Managing invasive species pathways in an era of globalization. J. Appl. Ecol. 46:10-18.

55. Ingram, J. S. I., Gregory, P. J., and Izac, A.-M. 2008. The role of agronomic research in climate change and food security policy. Agric. Ecosyst. Environ. 126:4-12.

56. International Statistics Flowers and Plants. 2004. Institut für Gartenbauökonomie der Universität Hannover, vol. 52. Germany.

57. Jactel, H., and Brockerhoff, E. G. 2007. Tree diversity reduces herbivory by forest insects. Ecol. Lett. 10:835-848.

58. Jeger, M. J., Pautasso, M., Holdenrieder, O., and Shaw, M. W. 2007. Modelling disease spread and control in networks: Implications for plant sciences. New Phytol. 174:179-197.

59. Jumpponen, A., and Jones, K. L. 2009. Massively parallel 454 sequencing indicates hyperdiverse fungal communities in temperate Quercus macrocarpa phyllosphere. New Phytol. 184:438-448.

60. Kaluza, P., Kölzsch, A., Gastner, M. T., and Blasius, B. 2010. The complex network of global cargo ship movements. J. R. Soc. Interface 7:1093-1103.

61. Keeling, M. 2005. The implication of network structure for epidemic dynamics. Theor. Pop. Biol. 67:1-8.

62. Keesing, F., Holt, R. D., and Ostfeld, R. S. 2006. Effects of species diversity on disease risk. Ecol. Lett. 9:485-498.

63. Klein, E., Laxminarayan, R., Smith, D. L., and Gilligan, C. A. 2007. Economic incentives and mathematical models of disease. Environ. Develop. Econ. 12:707-732.

64. Klein, W. 2006. Der bayerische Pflanzenschutzdienst stellt sich vor. Gesunde Pflanzen 58:3-8.

65. Kowalski, T., and Holdenrieder, O. 2009. Pathogenicity of Chalara fraxinea. For. Pathol. 39:1-7.

66. Kowalski, T., and Holdenrieder, O. 2009. The teleomorph of Chalara fraxinea, the causal agent of ash dieback. For. Pathol. 39:304-308.

67. Lamour, A., Termorshuizen, A. J., Volker, D., and Jeger, M. J. 2007. Network formation by rhizomorphs of Armillaria lutea in natural soil: Their description and ecological significance. FEMS Microbiol. Ecol. 62:222-232.

68. Lange, E., and Hehl-Lange, S. 2010. Making visions visible for long-term landscape management. Futures 42:693-699.

69. Lianga, J., and Tang, S. 2010. Optimal dosage and economic threshold of multiple pesticide applications for pest control. Math. Comp. Model. 51:487-503.

70. Linde, C. C., Zala, M., and McDonald, B. A. 2009. Molecular evidence for recent founder populations and human-mediated migration in the barley scald pathogen Rhynchosporium secalis. Mol. Phylogenet. Evol. 51:454-464.

71. Lively, C. M. 2010. The effect of host genetic diversity on disease spread. Am. Nat. 175:E149-E152.

72. MacDonald, J., Allen, C., Gadoury, D., Jacobi, W., Kelemu, S., Moyer, J., Murray, T., Ong, K., Pearson, C., Sherwood, J., and Vidaver, A. 2009. Education in plant pathology: Present status and future challenges. Plant Dis. 93:1238-1251.

73. MacLeod, A., Pautasso, M., Jeger, M. J., and Haines-Young, R. 2010. Evolution of the international regulation of plant pests and challenges for future plant health. Food Secur. 2:49-70.

74. Magarey, R. D., Colunga-Garcia, M., and Fieselmann, D. A. 2009. Plant biosecurity in the United States: Roles, responsibilities, and information needs. BioScience 59:875-884.

75. Manici, L. M., and Caputo, F. 2009. Fungal community diversity and soil health in intensive potato cropping systems of the east Po valley, northern Italy. Ann. Appl. Biol. 155:245-248.

76. Mansfield, J. W. 2009. From bacterial avirulence genes to effector functions via the hrp delivery system: An overview of 25 years of progress in our understanding of plant innate immunity. Mol. Plant Pathol. 10:721734.

77. Margosian, M. L., Garrett, K. A., Hutchinson, J. M. S., and With, K. A. 2009. Connectivity of the American agricultural landscape: Assessing the national risk of crop pest and disease spread. BioScience 59:141-151.

78. Martinez-Lopez, B., Perez, A. M., and Sanchez-Vizcaino, J. M. 2009. Combined application of social network and cluster detection analyses for temporal-spatial characterization of animal movements in Salamanca, Spain. Prev. Vet. Med. 91:29-38.

79. Mascheretti, S., Croucher, P. J. P., Kozanitas, M., Baker, L., and Garbelotto, M. 2009. Genetic epidemiology of the sudden oak death pathogen Phytophthora ramorum in California. Mol. Ecol. 18:4577-4590.

80. May, R. M. 2006. Network structure and the biology of populations. Trends Ecol. Evol. 21:394-399.

81. McDonald, B. A., and Linde, C. 2002. The population genetics of plant pathogens and breeding strategies for durable resistance. Euphytica 124:163-180.

82. McRae, C. F., and Wilson, D. 2002. Plant health as a trade policy issue. Australas. Plant Pathol. 31:103-105.

83. Merler, S., and Ajelli, M. 2009. The role of population heterogeneity and human mobility in the spread of pandemic influenza. Proc. R. Soc. B 277:557-565.

84. Midgley, G. F., Davies, I. D., Albert, C. H., Altwegg, R., Hannah, L., Hughes, G. O., O'Halloran, L. R., Seo, C., Thorne, J. H., and Thuiller, W. 2010. BioMove-An integrated platform simulating the dynamic response of species to environmental change. Ecography 33:612-616.

85. Miller, S. A., Beed, F. D., and Harmon, C. L. 2009. Plant disease diagnostic capabilities and networks. Annu. Rev. Phytopathol. 47:15-38.

86. Moreno-Risueno, M. A., Busch, W., and Benfey, P. N. 2010. Omics meet networks-Using systems approaches to infer regulatory networks in plants. Curr. Opin. Plant Biol. 13:126-131.

87. Moslonka-Lefebvre, M., Pautasso, M., and Jeger, M. J. 2009. Disease spread in small-size directed networks: Epidemic threshold, correlation between links to and from nodes, and clustering. J. Theor. Biol. 260:402411.

88. Mucha, P. J., Richardson, T., Macon, K., Porter, M. A., and Onnela, J.-P. 2010. Community structure in time-dependent, multiscale, and multiplex networks. Science 328:876-878.

89. Natale, F., Giovannini, A., Savini, L., Palma, D., Possenti, L., Fiore, G., and Calistri, P. 2009. Network analysis of Italian cattle trade patterns and evaluation of risks for potential disease spread. Prev. Veter. Med. 92:341350 .

90. Newman, M. E. J. 2003. The structure and function of complex networks. Soc. Indust. Appl. Math. Rev. 45:167-256.

91. Newton, A. C., Begg, G. S., and Swanston, J. S. 2009. Deployment of diversity for enhanced crop function. Ann. Appl. Biol. 154:309-322.

92. Nobis, M. P., Jaeger, J. A. G., and Zimmermann, N. E. 2010. Neophyte species richness at the landscape scale under urban sprawl and climate warming. Divers. Distrib. 15:928-939.

93. Opik, M., Metsis, M., and Daniell, T. J. 2009. Large-scale parallel 454 sequencing reveals host ecological group specificity of arbuscular mycorrhizal fungi in a boreo-nemoral forest. New Phytol. 184:424-437.

94. Pace, N. R. 2009. Mapping the tree of life: Progress and prospects. Microbiol. Mol. Biol. Rev. 73:565-576.

95. Pautasso, M., Dehnen-Schmutz, K., Holdenrieder, O., Pietravalle, S., Salama, N., Jeger, M. J., Lange, E., and Hehl-Lange, S. 2010. Plant health and global change-Some implications for landscape management. Biol. Rev. 85:729-755.

96. Pautasso, M., Harwood, T., Shaw, M., Xu, X., and Jeger, M. 2008. Epidemiological modeling of Phytophthora ramorum: Network properties of susceptible plant genera movements in the nursery sector of England and Wales. Pages 257-264 in: Proc. Sudden Oak Death III Sci. Symp., PSW-GTR-214. Pacific Southwest Research Station, Forest Service, U.S. Dep. Agric., Albany, CA.

97. Pautasso, M., Holdenrieder, O., and Stenlid, J. 2005. Susceptibility to fungal pathogens of forests differing in tree diversity. Pages 263-289 in: Forest Diversity and Function. Ecology Studies Vol. 176. M. SchererLorenzen, C. Koerner, and D. Schulze, eds. Springer, Berlin.

98. Pautasso, M., and Jeger, M. J. 2008. Epidemic threshold and network structure: The interplay of probability of transmission and of persistence in small-size directed networks. Ecol. Compl. 5:1-8. 
99. Pautasso, M., Moslonka-Lefebvre, M., and Jeger, M. J. 2010. The number of links to and from the starting node as a predictor of epidemic size in small-size directed networks. Ecol. Compl. 7:424-432.

100. Pautasso, M., Xu, X. M., Jeger, M. J., Harwood, T., Moslonka-Lefebvre, M., and Pellis, L. 2010. Disease spread in small-size directed trade networks: The role of hierarchical categories. J. Appl. Ecol. 47:13001307.

101. Pieterse, C. M. J., Leon-Reyes, A., Van der Ent, S., and Van Wees, S. C. M. 2009. Networking by small-molecule hormones in plant immunity. Nature Chem. Biol. 5:308-316.

102. Plantegenest, M., Le May, C., and Fabre, F. 2007. Landscape epidemiology of plant diseases. J. R. Soc. Interface 4:963-972.

103. Poulin, R. 2010. Network analysis shining light on parasite ecology and diversity. Trends Parasitol. 26:492-498.

104. Prospero, S., Grünwald, N. J., Winton, L. M., and Hansen, E. M. 2009. Migration patterns of the emerging plant pathogen Phytophthora ramorum on the West Coast of the United States of America. Phytopathology 99:739-749.

105. Raymond, B., and Hosie, G. 2009. Network-based exploration and visualisation of ecological data. Ecol. Model. 220:673-683.

106. Rodoni, B. 2009. The role of plant biosecurity in preventing and controlling emerging plant virus disease epidemics. Virus Res. 141:150-157.

107. Roelfs, A. P., and Groth, J. V. 1980. A comparison of virulence phenotypes in wheat stem rust populations reproducing sexually and asexually. Phytopathology 70:855-862.

108. Roos, J., Hopkins, R., Kvarnheden, A., and Dixelius, C. 2010. The impact of global warming on plant diseases and insect vectors in Sweden. Eur. J. Plant Pathol. 129:9-19.

109. Rothberg, J. M., and Leamon, J. H. 2008. The development and impact of 454 sequencing. Nat. Biotechnol. 26:1117-1124.

110. Salathé, M., and Jones, J. H. 2010. Dynamics and control of diseases in networks with community structure. PLoS Comp. Biol. 6:e1000736.

111. Scheiner, S. M. 2010. The intersection of the sciences of biogeography and infectious disease ecology. EcoHealth 6:483-488.

112. Scholthof, K. B. G. 2007. The disease triangle: Pathogens, the environment and society. Nat. Rev. Microbiol. 5:152-156.

113. Shah, M. A., Reshi, Z. A., and Khasa, D. P. 2009. Arbuscular mycorrhizas: Drivers or passengers of alien plant invasion. Bot. Rev. 75:397-417.

114. Shannon, P., Markiel, A., Ozier, O., Baliga, N. S., Wang, J. T., Ramage, D., Amin, N., Schwikowski, B., and Ideker, T. 2003. Cytoscape: A software environment for integrated models of biomolecular interaction networks. Genome Res. 13:2498-2504.

115. Shaw, M. W. 2009. Preparing for changes in plant diseases due to climate change. Plant Prot. Sci. 45:S3-S10.

116. Skelsey, P., Rossing, W. A. H., Kessel, G. J. T., and van der Werf, W. 2010. Invasion of Phytophthora infestans at the landscape level: How do spatial scale and weather modulate the consequences of spatial heterogeneity in host resistance? Phytopathology 100:1146-1161.

117. Skerratt, L. F., Garner, T. W. J., and Hyatt, A. D. 2010. Determining causality and controlling disease is based on collaborative research involving multidisciplinary approaches. EcoHealth 6:331-334.

118. Southworth, D., He, X. H., Swenson, W., Bledsoe, C. S., and Horwath, W. R. 2005. Application of network theory to potential mycorrhizal networks. Mycorrhiza 15:589-595.

119. Strogatz, S. H. 2001. Exploring complex networks. Nature 410:268-276.

120. Sugiura, S. 2010. Species interactions-area relationships: Biological invasions and network structure in relation to island area. Proc. R. Soc. B 277:1807-1815.

121. Surkov, I. V., Lansink, A. G. J. M. O., and van der Werf, W. 2009. The optimal amount and allocation of sampling effort for plant health inspection. Eur. Rev. Agric. Econ. 36:295-320.

122. Surkov, I. V., Lansink, A. G. J. M. O., Van der Werf, W., and Van Kooten, O. 2007. Designing optimal phytosanitary inspection policy-A conceptual framework and an application. Pages 39-54 in: New
Approaches to the Economics of Plant Health. A. G. J. M. O. Lansink, ed. Wageningen, the Netherlands.

123. Surkov, I. V., Lansink, A. G. J. M. O., van Kooten, O., and van der Werf, W. 2008. A model of optimal import phytosanitary inspection under capacity constraint. Agric. Econ. 38:363-373.

124. Surkov, I. V., van der Werf, W., van Kooten, O., and Lansink, A. G. J. M. O. 2008. Modeling the rejection probability in plant imports. Phytopathology 98:728-735.

125. Tero, A., Takagi, S., Saigusa, T., Ito, K., Bebber, D. P., Fricker, M. D., Yumiki, K., Kobayashi, R., and Nakagaki, T. 2010. Rules for biologically inspired adaptive network design. Science 327:439-442.

126. Thébault, E., and Fontaine, C. 2010. Stability of ecological communities and the architecture of mutualistic and trophic networks. Science 329:853-856.

127. Trapman, P. 2007. Reproduction numbers for epidemics on networks using pair approximation. Math. Biosci. 210:464-489.

128. Tsuda, K., Sato, M., Stoddard, T., Glazebrook, J., and Katagiri, F. 2009. Network properties of robust immunity in plants. PLoS Genet. 5:e1000772.

129. Tylianakis, J. M., Laliberté, E., Nielsen, A., and Bascompte, J. 2010. Conservation of species interaction networks. Biol. Conserv. 143:22702279.

130. Uno, G. E. 2009. Botanical literacy: What and how should students learn about plants? Am. J. Bot. 96:1753-1759.

131. Urban, D. L., Minor, E. S., Treml, E. A., and Schick, R. S. 2009. Graph models of habitat mosaics. Ecol. Lett. 12:260-273.

132. Vacher, C., Daudin, J.-J., Piou, D., and Desprez-Loustau, M.-L. 2010. Ecological integration of alien species into a tree-parasitic fungus network. Biol. Invas. 12:3249-3259.

133. Vacher, C., Piou, D., and Desprez-Loustau, M. L. 2008. Architecture of an antagonistic tree/fungus network: The asymmetric influence of past evolutionary history. PLoS One 3:e1740.

134. Van der Putten, W. H., Macel, M., and Visser, M. E. 2010. Predicting species distribution and abundance responses to climate change: Why it is essential to include biotic interactions across trophic levels. Phil. Trans. R. Soc. B 365:2025-2034.

135. Vellinga, E. C., Wolfe, B. E., and Pringle, A. 2009. Global patterns of ectomycorrhizal introductions. New Phytol. 181:960-973.

136. Venette, R. C., Kriticos, D. J., Magarey, R. D., Koch, F. H., Baker, R. H. A., Worner, S. P., Raboteaux, N. N. G., McKenney, D. W., Dobesberger, E. J., Yemshanov, D., De Barro, P. J., Hutchison, W. D., Fowler, G., Kalaris, T. M., and Pedlar, J. 2010. Pest risk maps for invasive alien species: A roadmap for improvement. BioScience 60:349-362.

137. Vernon, M., and Keeling, M. J. 2009. Representing the UK's cattle herd as static and dynamic network. Proc. R. Soc. B 276:469-476.

138. Viljanen-Rollinson, S. L. H., Parr, E. L., and Marroni, M. V. 2007. Monitoring long-distance spore dispersal by wind-A review. N.Z. Plant Prot. 60:291-296.

139. Waage, J. K., Woodhall, J. W., Bishop, S. J., Smith, J. J., Jones, D. R., and Spence, N. J. 2008. Patterns of plant pest introductions in Europe and Africa. Agric. Syst. 99:1-5.

140. Watts, D. J. 1999. Small Worlds: The Dynamics of Networks Between Order and Randomness. Princeton University Press, Princeton, NJ.

141. Webber, J. F., Mullett, M., and Brasier, C. M. 2010. Dieback and mortality of plantation Japanese larch (Larix kaempferi) associated with infection by Phytophthora ramorum. New Dis. Rep. 22:19.

142. Wu, X. M., Li, Y. R., Zou, L. F., and Chen, G. Y. 2007. Gene-for-gene relationships between rice and diverse avrBs3/pthA avirulence genes in Xanthomonas oryzae pv. oryzae. Plant Pathol. 56:26-34.

143. Xu, X. M., Harwood, T. D., Pautasso, M., and Jeger, M. J. 2009. Spatiotemporal analysis of an invasive plant pathogen (Phytophthora ramorum) in England and Wales. Ecography 32:504-516.

144. Zaffarano, P. L., McDonald, B. A., and Linde, C. C. 2009. Phylogeographical analyses reveal global migration patterns of the barley scald pathogen Rhynchosporium secalis. Mol. Ecol. 18:279-293. 